\title{
Adapting water allocation management to drought scenarios
}

\author{
P. Giacomelli, A. Rossetti, and M. Brambilla \\ Università degli Studi di Milano - Agricultural, Agri-food and Environmental Economics and Policy Department, Italy
}

Received: 4 October 2007 - Revised: 31 January 2008 - Accepted: 6 March 2008 - Published: 2 April 2008

\begin{abstract}
Climate change dynamics have significant consequences on water resources on a watershed scale. With water becoming scarcer and susceptible to variation, the planning and reallocation decisions in watershed management need to be reviewed. This research focuses on an in-depth understanding of the current allocation balance of water resources among competitors, placed along the course of the Adda River. In particular, during the summer period, the demand for water dramatically increases. This is due to the increase in irrigation activities in the lower part of the basin and to the highest peaks of tourist inflow, in the Como Lake and Valtellina areas. Moreover, during these months, the hydroelectric reservoirs in the upper part of the Adda River basin (the Valtellina) retain most of the volume of water coming from the snow and glacier melt. The existing allocation problem among these different competing users is exacerbated by the decreasing water supplies. The summer of 2003 testified the rise in a number of allocation problems and situations of water scarcity that brought about environmental and economical consequences. The RICLIC project is committed to the understanding of water dynamics on a regional scale, to quantify the volumes involved and offer local communities an instrument to improve a sustainable water management system, within uncertain climate change scenarios.
\end{abstract}

\section{Introduction}

1.1 The rise of water deficit on a regional scale

The amount of water in the world is finite. The number of people in the world is growing fast and water uses are growing even faster (Petit, 2001). This paper aims to discuss the problem of water scarcity in the Lombardy Region, one of

Correspondence to: A. Rossetti

(rossetti.andrea@unimib.it) the richest and most productive in Italy. During the last few years, the major river watersheds in Lombardy faced several situations of water deficit. During these periods, the supply of water was not able to satisfy the demand and consequently a loss of welfare for the watershed water users occurred. The diverted volumes for agriculture were reduced, thermoelectric and hydroelectric run-of-river power stations were forced to reduce electricity production, because the flowing water was not enough to guarantee a regular input for either cooling or moving the turbines. Furthermore, municipal water was rationed and in some cases, especially in the sub-alpine area, the aqueduct system was not able to supply all the houses. Sub-alpine lakes were affected by several problems due to the reduced hydrometric levels: first of all, the water uptake from the lake for municipal uses was dramatically limited and the water quality reduced. The industrial waste- waters and the municipal sewer pipes became visible, since their position was in some cases, situated above the lake surface. This situation led to both sanitary and health problems, as well as a decrease in tourist attractiveness, therefore affecting tourist income, so important in these areas. Moreover, the reduced hydrometric levels caused difficulties in both public and private navigation as well as serious shore instability and subsidence.

1.2 Regional Impact of Climate Change in Lombardy Water Resources: modelling and applications (RICLIC)

The increasing frequency of the aforementioned critical natural events has been a boost to carry out a more in-depth analysis of natural water cycles and their connections with human activities in Lombardy. This study is the preliminary outcome of the RICLIC project (Regional Impact of Climate Change in Lombardy Water Resources: Modelling and applications), funded by the Regional Agency for Environmental protection, the University of Milano - Bicocca and the main no-profit foundations for the environment (Fondazione

Published by Copernicus Publications on behalf of the European Geosciences Union. 
Lombardia per l'Ambiente). The main target of this threeyear project (started in January 2006) is to offer a methodology to analyse and assess the consequences of climate change on the Adda River basin, the biggest in Lombardy and one of the most important in northern Italy.

In the project, socioeconomic effects caused by climate change in the region are investigated. Experts from different scientific areas are committed, in order to attain a comprehensive picture of the complex relationships inside the system. The starting point is a dataset of meteorological data, pluviometric data, maximum and minimum temperatures, analyzed over the last century. The impact of climate change on surface and underground water resources and the effects on agriculture will be studied. Together, all the experts will analyse the physical consequences on the territory as a whole, combining their results to offer realistic physical scenarios. Starting from those scenarios, our research group is committed to the evaluation of the effects of water scarcity on the socioeconomic system and the quantification of the economic damage. The final aim of the project is to offer, by the end of 2008, a methodological scheme that will be employed to produce different water management options, in scenarios of climate change (EEA, 2007a).

This paper aims to present the approach that is being used to understand the socioeconomic elements within the river basin, that are mostly affected by the phenomena of water scarcity. Environmental and socioeconomic features are investigated, in order to understand how economic drivers influence water availability. Moreover, water demand and water supply are compared, to understand if the current regional water supply system is able to support the productive requirements of the area. In particular, a focus on the most critical periods during the year is performed at the present stage of the research. The physical scenarios are not available yet and therefore they will not be presented in this study.

\section{The concept of drought}

The discussion on the problem of water scarcity calls for a careful definition of the different meanings given to the term "drought". Following the central aim of this work, only the "disciplinary perspective of drought" will be discussed here, because the focus is on the distribution of water among different users. The United States National Drought Mitigation Centre (NDMC, 2006) offers different terms to distinguish the alternative disciplinary perspectives of drought: "meteorological drought", "agricultural drought", "hydrological drought", "hydrological drought and land uses" and "socioeconomic drought".

From the meteorological point of view, drought is defined by the rainfall conditions in a specific region of the world: the degree of dryness and the duration of the dry period, as compared to the average weather conditions in the area. "Agricultural drought" is focused on crops; the most important fac- tor to take into consideration is the correspondence between plant water demand and weather conditions. It is possible to define agricultural drought when conditions of precipitation shortage, reduced groundwater levels and high evapotranspiration levels occur at the same time, during the most susceptible stages of crop development. "Hydrological drought" is closely connected to a precipitation shortfall and water supply, but is out of phase with it. On a river basin scale, the "hydrological drought" shows how the deficiency of precipitation appears through the hydrologic system. The concept of "hydrological drought due to land use" expresses a condition of water deficit produced by a change in this use. Deforestation, land degradation and the construction of dams all affect the hydrological characteristics; these changes in land use widen the impact of meteorological drought well beyond the borders of the precipitation-deficient area. Land use change is one of the ways human actions alter the frequency of water shortage, even when no change in the frequency of meteorological drought has been observed. "Socioeconomic" drought occurs when the demand for an economic product exceeds the supply as a result of a weather-related shortfall in water supply. This definition links the supply and demand of some economic goods to elements of meteorological, hydrological and agricultural drought. As for land use, the socioeconomic drought lags the occurrence of meteorological drought, because it depends on the time and space of productive processes.

\section{Methodology}

\subsection{Cause-effect approach}

The method used to characterize the dynamics of the water management system in Lombardy over space and time is the one implemented by this research team to assess the economic effects of natural hazards (Sterlacchini et al., 2007). The aim is to make a connection between the causes of a certain phenomenon and the consequences that it could bring to the socioeconomic system. Economists have adapted the "dose-response" approach (Purchase, 2000) and applied it to the economic assessment of environmental risks (Pearce, 1998; Starmer, 1998; Polelli, 2006). In this approach the natural hazard (the drought) is the cause, described by its physical characteristics and the consequences on the study area are the effects. Considering drought scenarios, the main physical effects of drought events are the physical consequences of water scarcity: reduced flows discharge and reduced hydrometric levels in the lake. The "Mediterranean Water Framework Directive/EU Water Initiative Joint Process" (MED Joint Process WFD/EUWI, 2006) defines the drought impact as "the specific effect of drought on the economy, on the social life and on the environment, which are symptoms of vulnerability". Water shortage produces several socioeconomic costs to the water consumers (EEA, 2007b). 
In economic terms, such effects could directly or indirectly affect the socioeconomic system (Giacomelli, 2005). Direct damage quantifies, in economic terms, the physical consequences of drought. Indirect damage quantifies the economic consequences caused by the interruption of the economic activities (Bull, 1994).

\subsection{Application to water deficit scenarios}

The application of the cause-effect approach to drought scenarios may result more difficult than to landslides or floods. In fact, water scarcity cannot be delimited to a specific area and the elements involved are not easily identified. In fact, when a situation of water scarcity occurs, its effects on a river basin are widespread. Moreover, the socioeconomic damages do not depend solely on the natural phenomena but are also strongly influenced by the general water resource management and by its governance during the critical periods. In particular, the Adda River basin is a strongly regulated system therefore, during the cause-effect analysis its water resource management strategies need to be taken into account. In situations of water deficit, an in-depth analysis of the trade-off between supply and demand of water needs to be carried out, to identify its weaknesses, and its effects on the socioeconomic system, by the end of the research project. Different potential scenarios, combining each water deficit factor (meteorological, hydrological, land-use), will be drawn up and a quantification of the socioeconomic effects will be carried out for all of them.

\section{Study area}

\subsection{Physical characterization}

The Adda River basin covers a wide area, of about $7.979 \mathrm{~km}^{2}$, that extends across the Lombardy Region from north to south, following the total length of Adda River, $313 \mathrm{~km}$. It can be roughly subdivided into three main sectors: the Alpine area (Valtellina), Como Lake and the Po Plain. In the Valtellina the Adda flows through a large glacial valley, from north-east to south-west in the first part and from east to west in the second, for an overall length of $119 \mathrm{~km}$ and an area of $2598 \mathrm{~km}^{2}$ (Lombardy Region, 2006). Four important alpine Adda River sub-basins were not considered, since they are located on Swiss territory. On the other hand, the Lei and the Spoel basins were included in the study area, even though they do not physically belong to the Adda River basin but whose waters are artificially diverted into it for hydroelectric purposes. Some of the highest mountains in Europe surround this valley: among these, the Bernina, the Cevedale and the Adamello massif, characterized by the presence of glaciers. The overall surface of this alpine sector amounts to $3212 \mathrm{~km}^{2}$, and consists of two main sub-basin sectors. After having passed through the valley, the Adda River becomes a tributary of the pre-alpine glacial Como Lake, surrounded by mountains. Because of its geophysical characteristics, the main inhabited areas are situated along the coastline. In Lecco, the Adda flows out from the lake, across the Po Plain, and ends in Castelnuovo Bocca d'Adda, where it joins the Po River, a few kilometres upstream from Cremona.

\subsection{Hydrological system}

The alpine catchment of the Adda River ranges over altitudes from $4050 \mathrm{~m}$. to $198 \mathrm{~m}$ a.s.l. Its annual runoff cycle is greatly influenced by snow storage and melt dynamics and is regulated by means of 21 hydroelectric reservoirs that retain at their maximum capacity, an overall volume of 419.10 millions of cubic meters $\left(\mathrm{Mm}^{3}\right)$. One of the largest reservoirs, S.Giacomo di Fraele $\left(64 \mathrm{Mm}^{3}\right)$, collects water $\left(90 \mathrm{Mm}^{3} / \mathrm{yr}\right)$ flowing from a diversion of the Spoel River, which is physically part of the Inn River basin. Moreover, this part of the watershed is characterized by the presence of several dams that provide a more sensitive regulation, especially for flood prevention.

At the bottom of the Valtellina (198 m a.s.1.), the Adda flows into Como Lake, with an annual average discharge of $88.0 \mathrm{~m}^{3} / \mathrm{s}$. The lake has an extension of $145 \mathrm{~km}^{2}$, a maximum depth of $410 \mathrm{~m}$ and an average depth of $155 \mathrm{~m}$. The lake regulation is provided by the presence of a dam at its very end in Lecco-Olginate by which, hydrometric levels and water discharges are controlled.

The lowest sector of the watershed is conventionally delimited between the Lecco-Olginate dam (198 m a.s.l., average yearly discharge of $158.2 \mathrm{~m}^{3} / \mathrm{s}$ ) and where the Adda joins the Po River ( $36 \mathrm{~m}$ a.s.l., average yearly discharge of $287.6 \mathrm{~m}^{3} / \mathrm{s}$ ). Along its course through the Po Plain, the Adda is diverted for agricultural and industrial purposes by means of several catchments and sub-catchments, which in some cases bring water to productive areas in different watersheds. The amount of water diverted varies throughout the year to satisfy the oscillation in the demand of water, generated by the intensive human activities. In this sector, Adda River gets water from two main influent, Brembo and Serio River, flowing from the Orobic Alps, whose average discharge amounts to $20.8 \mathrm{~m}^{3} / \mathrm{s}$ and $18.20 \mathrm{~m}^{3} / \mathrm{s}$, respectively (Lombardy Region, 2006).

\subsection{Socioeconomic system}

The first step of the analysis was to identify the exact area directly affected by the Adda River water dynamics. All along its course, there is quite a complex overlapping of authorities: the municipality is the main administrative unit, the management of water for civil purposes is carried out by the provincial authority and the Lombardy Region is in charge of administrating the whole system. The municipality is the administrative unit selected, as it best suits the purpose of the analysis. Given the complexity of the water system, it was chosen to consider the municipalities whose economy 
Table 1. Demographic characterization of the three sub-areas. (Source: ISTAT, 2001).

\begin{tabular}{lccccc}
\hline & $\begin{array}{c}\text { No. of } \\
\text { provinces }\end{array}$ & $\begin{array}{c}\text { No. of } \\
\text { municipalities }\end{array}$ & Population & $\begin{array}{c}\text { Surface } \\
\left(\mathrm{km}^{2}\right)\end{array}$ & $\begin{array}{c}\text { Density } \\
\left(\mathrm{inhab} / \mathrm{km}^{2}\right)\end{array}$ \\
\hline Valtellina & 1 & 78 & 174116 & 3212 & 54 \\
Como Lake & 2 & 57 & 267344 & 700 & 382 \\
Po Plain & 5 & 125 & 658998 & 1119 & 589 \\
\hline
\end{tabular}

\section{Floating population}

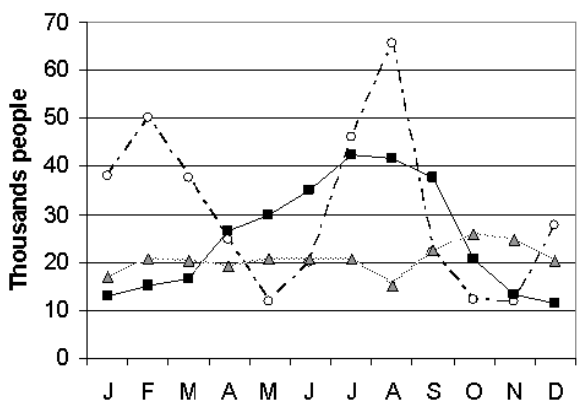

Fig. 1. Monthly oscillation of floating population for the three subareas (Source: Lombardy Region, 2006).

strictly depends on the Adda River water supply system. In this way, the data presented in the following chapters refer to the selected 260 municipalities, whose water resources could be directly attributed to the Adda. To understand how water resources are exploited in the Adda River basin, the present chapter characterizes the main socioeconomic features in the River basin, by looking in depth at the three different areas presented before. As previously explained, the three areas are significantly different, not only from a physical point of view, but also on the basis of their socioeconomic characteristics; for these reasons, they will be separately analysed.

Starting from the North, the areas will be described following the flow of the Adda down to where it joins the Po. The Valtellina is situated entirely within the Sondrio Province; the analysis will examine data from 78 municipalities, for a population of over 174000 inhabitants. Because of the physical characteristics of the valley, railway and road connections are not streamlined. This feature has given rise to a huge flow of commuters from the Valtellina that work in the nearest most industrialized provinces (Como, Lecco and Milano Provinces) travelling to and from every day. Indeed, Fig. 1 shows that in holiday seasons the floating population in the Valtellina increases considerably and consists of both tourists and residents that work in the different cities.

Valtellina's economy is mainly based on viticulture, cattle breeding and tourism. Tourism represents more than one third of the overall added value produced in the Valtellina, (3836 million Euros in 2004; source: UNIONCAMERE,
Table 2. Utilized Agricultural Area (UAA). (Source: ISTAT, 2001).

\begin{tabular}{lccc}
\hline & surface (ha) & UAA (ha) & $\%$ \\
\hline Valtellina & 321200 & 92363 & 29 \\
Como Lake & 70000 & 6208 & 9 \\
Po Plain & 111900 & 90317 & 81 \\
\hline
\end{tabular}

2005). As a matter of fact, the service sector generates $69.1 \%$ of the overall province income; this is a significant result, considering that the service sector in Valtellina is tourism oriented. On the other hand, agriculture holds a very important role, with the production of some high quality products, like CDO (Controlled Designation of Origin) wines and PDO (Protected Designation of Origin) cheeses and meat.

The population of the Como Lake sector is over seven times bigger than in the Valtellina. Historically, communities settled along the lakeside to get food and water and a faster connection with the other side of the lake, for communication and commercial exchanges. The economy in this area shows some differences between the three branches of the lake: the northern branch, from Bellagio to Colico, the eastern branch, in the Lecco Province and the western branch, in the Como Province. The economy of the northern branch is more influenced by tourism and over the last years has been attracting more and more tourists, $60 \%$ coming from abroad. In the southern branches, industries represent the leading force of local economy, and local activities are strongly influenced by the lake. In fact, while in the eastern branch (the Lecco Province), local economy is based on metallurgical industry, in the western branch (the Como Province municipalities overlooking the lake), the most important economic activity is the silk textile industry, that forms $21 \%$ of Province industry.

The plain sector is part of the most important productive area in Italy. The whole area along the Adda attracts a huge number of people, thanks to the numerous job opportunities in different sectors, generating intensive daily flows of commuters. The land is intensely exploited: $81 \%$ of the total area of the considered municipalities (see Table 2) is classified as "Utilized Agricultural Area" (UAA). The main production of the agriculture sector in Lombardy is cattle breeding, as approximately $65 \%$ of the added value is generated by this sector; on the contrary, in the national Italian economy 

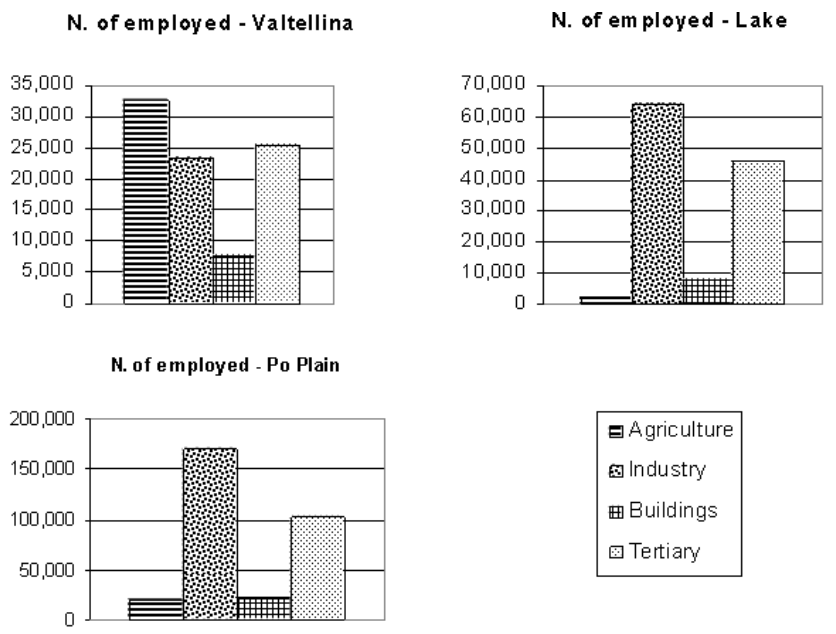

Fig. 2. Number of people employed in the different productive sectors, for each area. (Source: own elaboration based on ISTAT, 2001).

the breeding sector accounts for only $30 \%$ of the total added value.

\section{Human activities and hydrological cycles}

\subsection{Water supply}

Lombardy water supply system has always been very rich in water and therefore, over the centuries with the rapid increase in human water-dependent activities it has been modified to improve its efficiency. The first works were carried out during the Middle Ages to drain the wetlands and make them suitable for agriculture. Afterwards, artificial channels, dams and water pumps were built to increase water availability and to prevent flooding. The socioeconomic system has grown strictly dependent on the water supply system, since the water availability has historically represented an important factor for the expansion of human activities.

From the very beginning of the last century until the 1960s, the construction of hydroelectric reservoirs has increased the water stock capacity of the watershed, retaining water in situations of surplus. Moreover, in 1946 the building of the Lecco-Olginate dam, at the end of Como Lake, provided an effective instrument for the regulation of the output discharges from the lake to the lowest sectors of the Adda Basin. The regulatory agency (the Adda River Authority-Consorzio dell'Adda) plays a central role in the water allocation process and, by means of opening and closing the dam, provides the best solution to satisfy irrigation, industrial activities and run-on-river hydroelectric power stations (Consorzio dell'Adda, 2003). The average summer instantaneous stream flow, before the construction of Lecco-Olginate dam, measured around $190 \mathrm{~m}^{3} / \mathrm{s}$ and, according to this constraining discharge value, the amounts of water rights intended for hu-

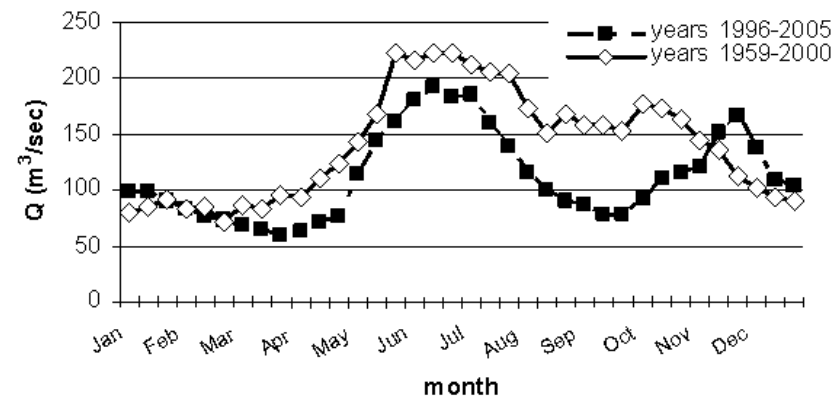

Fig. 3. Average ten day aggregate discharges from Lecco-Olginate dam. Period: 1959-2000 vs. 1996-2005. (Source: own elaboration based on the Consorzio dell'Adda data, 2006).

man activities were calculated. The dam made it possible to increase the average summer discharge to values estimated at around $220 \mathrm{~m}^{3} / \mathrm{s}$ that, until now, has represented the upper boundary for water dependent human activities, in the lower part of the Adda River basin. Como Lake's absolute capacity is estimated at around $22500 \mathrm{Mm}^{3}$. The hydrometric level of regulation ranges from $-40 \mathrm{~cm}$ to $120 \mathrm{~cm}$ (Lecco-Olginate hydrometer) and corresponds to a maximum available regulation capacity of $254.3 \mathrm{Mm}^{3}$. This volume is not very significant, since it represents $9 \%$ of the average annual input flow from the Valtellina into the lake (Fuentes hydrometric station). As stated before, the multi-target regulation of output discharges by the Adda River Authority needs to take into account both the peaks in water requirements and meteorological events. Figure 3 shows details of the oscillation of the instantaneous stream flows (ten-day aggregate) from Lecco-Olginate dam, throughout the year, for the years 1959 to 2000 and the more recent 1996 to 2005 .

The 1959-2000 curve shows the average historical trends of the lake regulation: a rapid increase in discharges from the beginning of April to the maximum levels of regulation discharges $\left(220 \mathrm{~m}^{3} / \mathrm{s}\right)$, in June and July; after that period, during August, the discharges from the Lecco-Olginate dam start to decrease until the autumn peaks when, in response to high precipitations, the Adda River Authority increases the outflows, to prevent floods in the coastal cities, Como in particular. The comparison between the long period and the more recent short period curve shows significant differences. The irrigation period outflows are limited to the period from the middle of June to the middle of August, and the highest average discharge levels are measured at around $192 \mathrm{~m}^{3} / \mathrm{s}$, during the last ten days of June. Another interesting difference regards the autumn period: the 1996-2005 curve is characterized by very low discharge levels during September and October $\left(80-90 \mathrm{~m}^{3} / \mathrm{s}\right)$ and a peak in the last ten days of November. This may be due to local climatic variations in the Alpine and sub-Alpine regions that delayed the autumnal precipitation peak (a thirty days delay), therefore, snow accumulation processes were delayed too. 
Table 3. Difference (Years 1959-2000 vs. years 1996-2005) in the average annual and summer discharges and volumes at the Lecco-Olginate dam. (Source: own elaboration based on the "Consorzio dell'Adda", 2006).

\begin{tabular}{|c|c|c|c|c|c|c|c|}
\hline $\begin{array}{l}\text { Yearly } \\
\text { average }\end{array}$ & $\begin{array}{c}\text { Average } \\
\text { discharge } \\
\left(\mathrm{m}^{3} / \mathrm{s}\right)\end{array}$ & $\begin{array}{l}\text { Average } \\
\text { volume } \\
\left(\mathrm{Mm}^{3}\right)\end{array}$ & & $\begin{array}{c}\text { Summer } \\
\text { average } \\
\text { (Jun-Aug) }\end{array}$ & $\begin{array}{c}\text { Average } \\
\text { discharge } \\
\left(\mathrm{m}^{3} / \mathrm{s}\right)\end{array}$ & $\begin{array}{l}\text { Average } \\
\text { volume } \\
\left(\mathrm{Mm}^{3}\right)\end{array}$ & \\
\hline Years 1959-2000 & 140.65 & 4435.42 & & & 197.67 & 1571.27 & \\
\hline Years 1996-2005 & 112.40 & 3544.23 & & & 149.88 & 1191.38 & \\
\hline Water deficit & -28.25 & -891.19 & $-20.09 \%$ & & -47.79 & -379.89 & $-24.18 \%$ \\
\hline
\end{tabular}

Table 4. Difference (Years 1959-2000 vs. years 1996-2005) in the average annual and summer discharges and volumes at the Fuentes hydrometric station. (Source: own elaboration based on the "Consorzio dell'Adda", 2006).

\begin{tabular}{|c|c|c|c|c|c|c|c|}
\hline $\begin{array}{l}\text { Yearly } \\
\text { average }\end{array}$ & $\begin{array}{c}\text { Average } \\
\text { discharge } \\
\left(\mathrm{m}^{3} / \mathrm{s}\right)\end{array}$ & $\begin{array}{l}\text { Average } \\
\text { volume } \\
\left(\mathrm{Mm}^{3}\right)\end{array}$ & & $\begin{array}{c}\text { Summer } \\
\text { average } \\
\text { (Jun-Aug) }\end{array}$ & $\begin{array}{c}\text { Average } \\
\text { discharge } \\
\left(\mathrm{m}^{3} / \mathrm{s}\right)\end{array}$ & $\begin{array}{l}\text { Average } \\
\text { volume } \\
\left(\mathrm{Mm}^{3}\right)\end{array}$ & \\
\hline Years 1959-2000 & 88.14 & 2779.62 & & & 122.92 & 977.03 & \\
\hline Years 1996-2005 & 88.66 & 2796.05 & & & 123.17 & 979.03 & \\
\hline Water deficit & +0.52 & +16.43 & $+0.59 \%$ & & +0.25 & +2.00 & $+0.20 \%$ \\
\hline
\end{tabular}

Table 5. Difference (Years 1959-2000 vs. years 1996-2005) in the number and percentage of days with the hydrometric level of Como Lake below zero $\mathrm{cm}$ height. (Source: own elaboration based on the "Consorzio dell' Adda", 2006).

\begin{tabular}{ccccc}
\hline & \multicolumn{2}{c}{ Year } & \multicolumn{2}{c}{ Summer (Jun-Aug) } \\
& days & $\%$ & days & $\%$ \\
\hline Years 1959-2000 & 3572 & 23.30 & 191 & 4.42 \\
Years 1996-2005 & 1621 & 44.39 & 171 & 18.59 \\
\hline
\end{tabular}

Table 3 shows that these lower discharge values correspond to an average decrease of 891.19 million cubic metres per year $(-20.09 \%)$ while a comparison focused on the summer months (June to August) shows an average deficit of 379.89 million cubic metres $(-24.18 \%)$. In fact, water availability for human activities in the last decade were significantly reduced.

The trend shown in Fig. 3 is also confirmed by the analysis of the Como Lake input flows, measured in Fuentes hydrometric station, at the bottom of the Valtellina (Fig. 4), where it is possible to identify the one-month delay of the autumnal positive peak. Nevertheless, the curves referring to the periods 1959-2000 and 1996-2005 do not present significant differences during the summer period (June-August).

Table 4 shows that the discharges in the Fuentes hydrometric station in the decade 1996-2005 are characterized by a slight increase; hence, the general water deficit measured at the Lecco-Olginate dam is not due to a reduced flow from the Valtellina. We suppose that a large part of the summer discharges from Fuentes comes from the snow and glacier

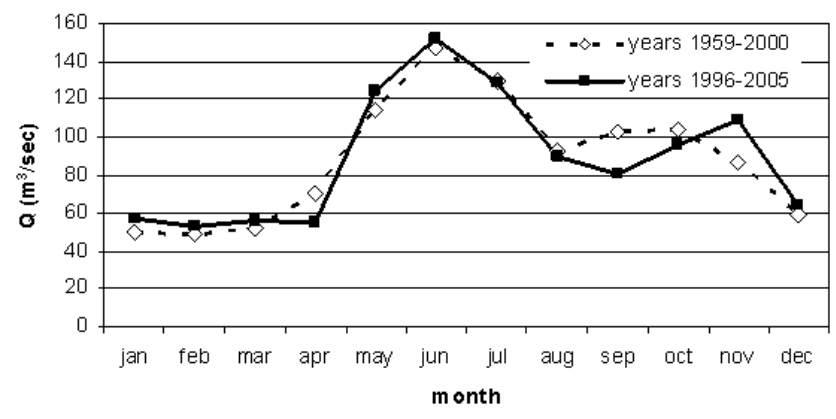

Fig. 4. Average ten-day aggregate discharges from the Fuentes hydrometric station. Period 1959-2000 vs. 1996-2005. (Source: own elaboration based on the Consorzio dell' Adda data, 2006).

melt. The overall input to Como Lake, is also influenced by its minor alpine and sub-alpine mainly torrential tributaries, whose summer dynamics are dependant on the distribution of the precipitations. A considerable reduction of precipitations in summer could be the origin of such variation between the inflow and the outflow measured in the Fuentes and LeccoOlginate stations, respectively.

The analysis of the hydrometric levels of Como Lake for the periods 1959-2000 and 1996-2005 (Table 5) highlights a situation of water scarcity during the last decade. The increase of days with the hydrometric level below zero level is significant, especially during the summer period (JuneAugust), with an increase from $4.42 \%$ to $18.45 \%$.

As stated before, low hydrometric levels rise sanitary problems, serious shore instability and environmental consequences, and a general reduction in tourist attractiveness in the lake area. 
Table 6. Water rights divided by sub-areas and human activities in $\mathrm{Mm}^{3} / \mathrm{yr}$. (Source: own elaboration based on the Lombardy Region, 2006).

\begin{tabular}{lcccccc}
\hline & $\begin{array}{c}\text { Animal farming, } \\
\text { Anti-fire }\end{array}$ & Fish farming & Municipal & Industry & Irrigation & Overall \\
\hline Valtellina & 31.22 & 146.37 & 79.89 & 31.24 & 187.85 & 476.57 \\
Como Lake & 8.31 & 1.1 & 105.88 & 53.57 & 5.6 & 174.46 \\
Po Plain & 164.76 & 288.73 & 291.05 & $1,977.14$ & 3500 & 6221.68 \\
OVERALL & 204.29 & 436.2 & 476.83 & 2061.95 & 3693.45 & \\
\hline
\end{tabular}

\subsection{Water demand}

5.2.1 Static analysis of water demand: water rights volumes

The socioeconomic activities situated within the Adda River watershed generate a great overall water demand on the supply system. The data in Table 6 show the volumes of water rights assigned by the Regional Water Authority on a municipal scale for the different human activities, aggregated for the considered sub-areas (Lombardy Region, 2006). Water rights, presented in millions of cubic metres per year, can be considered as the heart of the water allocation system because they aggregate surface diversions, underground and spring water. They do not quantify actual volumes, since they are estimated and not directly measured. The Regional Water Authority is in charge of evaluating every request for water rights in order to be able to avoid a waste of resources and grant an equitable annual average amount of water, in proportion to the actual users' needs. For instance, water rights for irrigation purposes are estimated combining the irrigated area extension, the crop types and the irrigation techniques employed. On the other hand, the amount of industrial water rights is estimated by the technical analysis of every productive process that involves the use of water. The significance of water rights is to establish a maximum limit of water consumption allowed for each users; in fact, it cannot exceed the respective water rights limit and it can be far lower. The overall water rights volumes do not correspond to the actual amount of flowing water, since they may be employed several times by multiple users along the course of the river. Besides, since water rights describe an overall annual amount of the resource, they are not suitable for the analysis of the variation over time of the water demand. The water rights assigned for hydroelectric power production are not considered in this study, since hydroelectricity production is a nonconsumptive water use and at the same time does not alter the water quality.

Despite the aforementioned limitations, it was decided to consider and analyse the water rights data, since they are the only available ones detailed for each user on a municipal scale. Nevertheless, even though in some cases they can overestimate the actual water demand levels, water rights volumes are able to provide a preliminary picture of the main water-demanding human sectors of the areas considered and they guarantee a reasonable assessment for the analysis on a regional scale.

The greatest water demanding activities are industry and agriculture on the Po Plain: the overall amount of water rights represents $90 \%$ of the entire watershed. Municipal and fish farming uses are considerably significant too, especially in the Como Lake and Po Plain sub-areas. The overall annual water right for industry $\left(2100 \mathrm{Mm}^{3} / \mathrm{yr}\right)$ are calculated considering both the industrial activities and the thermoelectric power production. The volumes of water rights for these activities amount to $264.95 \mathrm{Mm}^{3} / \mathrm{yr}$ and to $1797 \mathrm{Mm}^{3} / \mathrm{yr}$, respectively. The thermoelectric power plants, that use water for cooling purposes, are located on the Po Plain and they divert the water from an artificial channel of Adda River, e.g. Muzza (Lombardy Region, 2006).

\subsubsection{Dynamic evaluation of water demand: identification of critical periods}

The socioeconomic activities situated within the Adda River watershed generate a demand of water that is characterized by several fluctuations during the year, depending on the needs. While the water demand coming from manufacturing industries and thermoelectric power stations can be considered constant, municipal and agricultural needs show significant variations throughout the year. Moreover, alpine hydroelectric dams retain and release water from the reservoirs, according to the market requirements, which means day/night and/or seasonal variations. The annual average volumetric data (water rights volumes) seem inadequate to describe such situations localized in time, since they may potentially arise during short periods of the year. Hence, the analysis of more detailed data, where available, is needed; they should be provided with temporal information (on a monthly basis), in order to be able to focus on those critical months of the year, when the scarcity of water creates competition among the users.

The most critical period of the year for the water supply system is the summer. During this season, a dramatic increase in water demand leads to a shortage in the resource's availability and the supply system has to face a situation of stress. The allocation balance among all the competing water users within the basin may therefore be constrained and 
Table 7. Irrigated UAA and irrigation techniques of the Adda River basin. Source: own elaboration based on ISTAT, 2001).

\begin{tabular}{ccccccc}
\hline & \multicolumn{2}{c}{ UAA } & \multicolumn{4}{c}{ Irrigation techniques } \\
& UAA & $\begin{array}{c}\text { Irrigated } \\
\text { UAA }\end{array}$ & $\begin{array}{c}\text { Surface } \\
\text { irrigation }\end{array}$ & Flood & Spray & Drip \\
\hline ha & 90317 & 69057 & 62946 & 1247 & 4677 & 187 \\
$\%$ & & $75.27 \%$ & $90.81 \%$ & $1.80 \%$ & $6.75 \%$ & $0.27 \%$ \\
\hline
\end{tabular}

in some cases this situation may lead to welfare losses and economic damage. We hereby describe the activities characterized by a significant variation in water demand throughout the year and draw a preliminary scheme of the oscillation in water demand.

Agriculture is the most water-demanding productive sector of the Po Plain, particularly in the summer. During the irrigation period (from June to August) it demands large amounts of water from the watershed supply system (Lombardy Region, 2003). Indeed, the 8 main river diversions, that bring water from the Adda River to the middle and lower Po Plain irrigation districts, significantly increase their overall average discharges. Figure 5 shows the trend of the overall measured amount of diverted water and its increase from $39.29 \mathrm{~m}^{3} / \mathrm{s}$ (winter season, from September to May) to $141.17 \mathrm{~m}^{3} / \mathrm{s}(+359.31 \%)$. The overall measured volume diverted for irrigation purposes during the period from June to August amounts to $1122.16 \mathrm{Mm}^{3}$, while the overall annual measured volume amounts to $2042.30 \mathrm{Mm}^{3}$. The latter value is very different from the annual water rights value for irrigation on the Po Plain, which is estimated at around $3500 \mathrm{Mm}^{3}$ (see Table 5). The measured values seem more reliable in providing a more accurate description of the irrigation activities demand, also because of their monthly measurement scale.

This is due to the extensive presence of surface irrigation that represents the main irrigation technique employed within the Adda watershed (see Table 7). In surface irrigation, large amounts of water are brought to the fields and flow along the ground among the crops; it is a very cheap but very inefficient technique, as about $50 \%$ of the irrigation water is wasted and percolates to the groundwater table (Ribaudo, 2004).

During the same period, Como Lake and the Valtellina areas receive a great number of tourists in their territory. These areas have high tourist accommodation facilities, either in hotels or other infrastructures, such as campsites and holiday homes. The arrival and presence of tourists is very significant especially during July and August and during January and February. During the summer months, the overall floating population, received in Como Lake and the Valtellina tourist municipalities, is estimated at around $16 \%$ and $38 \%$ of the resident population, respectively. In both the Valtellina and Como Lake areas, the majority of tourists stay

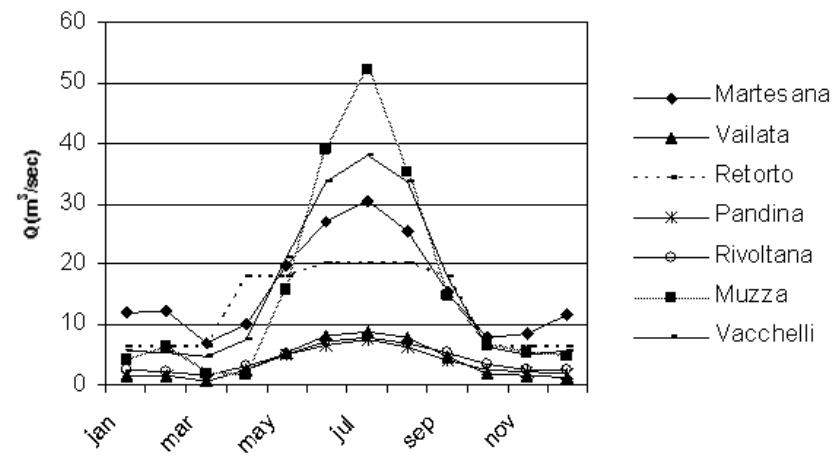

Fig. 5. Average monthly discharge of the Adda river diversions for irrigation purposes. (Source: own elaboration based on the Lombardy Region data, 2006).

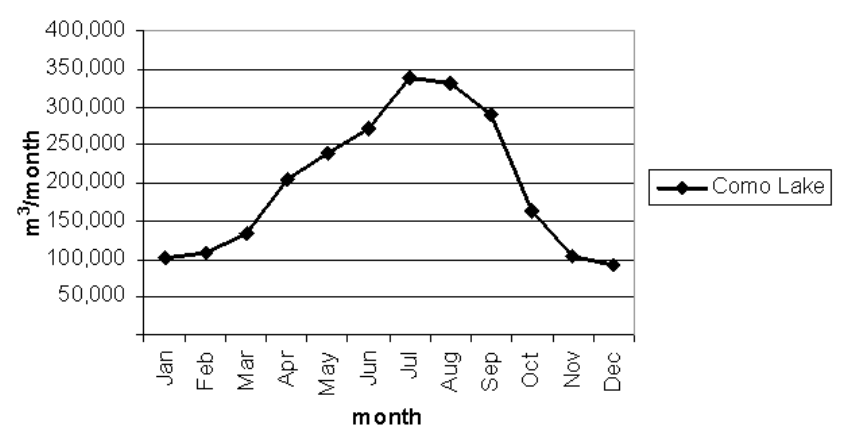

Fig. 6. Water demand of floating population, Como Lake. (Source: own elaboration based on Lombardy Region data, 2006).

in holiday homes $(79.04 \%$ and $81.96 \%$, respectively) while the rest are hosted in hotel facilities. The peaks of these arrivals and presences are responsible for a significant increase in the municipal water demands for the urban water delivery aqueducts. Figures 6 and 7 show the peaks of the monthly average water demand due solely to the floating population's water needs (in this case, the floating population is assumed to coincide with tourist flows). The amount of cubic metres have been calculated assuming an average daily water consumption of 200 litres for the holiday home tourist and of 530 litres for those accommodated in hotel structures (Lombardy Region, 2006). In fact, this latter higher value of daily consumption is obtained because it considers the water uses coming from the facilities provided by the hotels, such as swimming and thermal pools, gyms, restaurants and so on. The figures highlight the differences between tourism in the two areas. The distribution of tourist water consumption in the Valtellina shows two peaks corresponding to the summer and winter seasons while in the lake area it slightly increases in spring and reaches its maximum in July.

As stated above, hydroelectric power producers alter the river basin's natural water cycles that during summer would expect a greater water input coming from the ice and snow melt. In this period, these activities retain large amounts 
of water in their reservoirs. The maximum capacity of the hydroelectric reservoirs in the Valtellina amounts to $419.10 \mathrm{Mm}^{3}$. The hydroelectric companies modulate the accumulation/release strategies considering both the natural cycles and energy demand peaks, with the aim of maximizing their overall income. Hence, they employ the water, accumulated during the snow melting periods, to guarantee an efficient hydroelectric production during autumn, when the electricity demand is higher. The effect of these activities is to turn a natural flow into an artificial stock and to hold it for future uses. Basically, it means that hydroelectric power producers increase their overall water demand during summer, when the resource is scarcer, and conflict with other users. The overall amount of water employed for the hydroelectric power production in the year 2006 amounted to 2489 million cubic metres (Sondrio Province, 2006). A temporal analysis of the accumulation/release cycles of hydroelectric reservoirs is needed but it is difficult to be performed because of the confidential nature of this data.

\subsection{Water supply and demand: a critical analysis}

The analysis of static and dynamic features in supply and demand led to a schematization of the complex interrelationship between an environmental component and the socioeconomic system. The historical water abundance in this region gave rise to many human activities, whose production system has always been based on the water resource availability. The analysis of the available data, showed the presence of reduced water availability during the decade 1996-2005. In particular, the analysis of the hydrometric levels and Como Lake's output discharges highlighted during the summer period, an exacerbation of water scarcity, while water demand is higher due to the presence of tourists and irrigation. Agriculture is, probably, the most critical water-demanding human activity in the study area. It needs large volumes of water, concentrated in a very short period. Moreover, because of its old delivery system of channels and diversions and the widespread use of the surface irrigation technique, its use can not be considered very efficient.

At this stage of the project, it is not possible to draw general hypothesis of management in scenarios of water scarcity. The agriculture has been identified as the most critical sector in water demand dynamics; besides, its delivery and irrigation structures are old and its laws seem inadequate to regulate the current situation. $90.81 \%$ of the irrigated agriculture areas employ the surface irrigation technique, which uses large amounts of water. The volumes of water used for a single irrigation event amount to $900 \mathrm{~m}^{3} / \mathrm{ha}$ (Ribaudo, 2004), the same quantity employed by the flood irrigation, the very water-demanding technique used for rice cultivation. A preliminary hypothesis aimed at reducing the agriculture water demand, should take into account the switch to more efficient irrigation techniques of part of the irrigated areas. Spray irrigation which employs $250 \mathrm{~m}^{3} / \mathrm{ha}$ (Ribaudo, 2004), enables

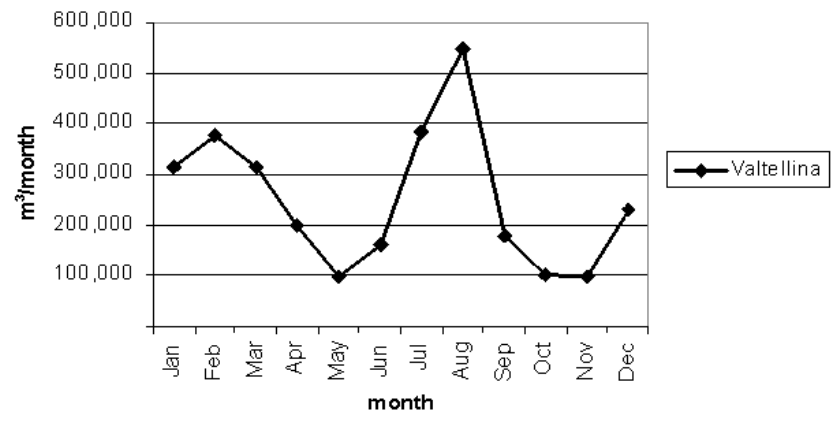

Fig. 7. Water demand of floating population, Valtellina. (Source: own elaboration based on Lombardy Region data, 2006).

a saving of $650 \mathrm{~m}^{3} / \mathrm{ha}$ per single irrigation event. In the current situation, spray irrigation is only employed on $6.75 \%$ of the overall irrigated surface. In the hypothesis of switching a part of the area (e.g. 20\%), which is at present irrigated by surface irrigation, the overall volume of water saved would amount to $8182980 \mathrm{~m}^{3}$ per single irrigation event. Further investigation should allow a more accurate management hypothesis for agriculture techniques to be drawn and consider their impacts on the energy demand. Moreover, the analysis of different sectors could lead to other solutions and improvements.

\section{Discussion and future development}

All users within the hydrologic unit become increasingly interdependent as water becomes scarcer. That is, each use can affect the quantity or quality of water available to others and because ground and surface water supplies are likely to be naturally connected, use of water from one source affects the availability of water from the other (Frederick, 1997). Therefore, the allocation strategy of the river basin authority is accurately discussed and planned in response to the contingent situations. Nevertheless, in some cases, when the severity of the water deficit situations becomes critical, the regulation methods are not effective and the entire socioeconomic system is put under stress (Wood et al., 1997).

This paper presents the main features of water supply and demand in the Adda River basin, in order to produce a preliminary picture of the volumes involved over space and time. The presented results are the preliminary outcomes of a three-year project, whose final aim is to widen the knowledge of regional water dynamics and allocation systems. Climate change must be considered in the analysis, as it represents a new element that contributes to the overall uncertainty characterizing the system. The project will provide a multi-disciplinary instrument to highlight the weaknesses in the water allocation balance and to support the regulation processes. Interest in problems related to water management is increasing in public opinion; in fact, in 2007 Lombardy 
Public Authority set the "Patto per l'acqua", a round table where all the stakeholders, from both the scientific and political sides, are invited to discuss, share their knowledge and find solutions to enhance water regulation, not only in emergency periods, but also for ordinary decisions.

Acknowledgements. This research is carried out within the framework of the RICLIC project, funded by Università degli Studi di Milano Bicocca, Fondazione Lombardia per l'Ambiente (The Lombardy Environment Foundation) and the Regional Agency for Environmental Protection. This paper has been discussed by the authors: P. Giacomelli wrote the paragraphs 1, 2, 6, M. Brambilla wrote the paragraphs 3 and 4 and A. Rossetti wrote the paragraph 5. The authors are grateful to S. Fuchs, A. Pasuto and the two other anonymous reviewers for the helpful comments and suggestions on the manuscript.

Edited by: S. Fuchs, M. Bründl, R. Bernknopf, and T. Glade Reviewed by: P. Alessandro and two other anonymous referees

\section{References}

Bull, R.: Disaster Economics, Disaster Management Training Programme, United Nations Development Programme, 1994.

Consorzio dell'Adda: Gli effetti della regolazione sulle portate dell' Adda e sulle piene del Lago di Como, 12, Milano, 2003.

Consorzio dell'Adda: Hydrological daily data, http://www.laghi. net/Adda/index.asp?Disp=idrometro, last accessed 18 July 2007, 2006.

EEA:.. European Environmental Agency. Climate change and water adaptation issues, EEA Technical report 2/2007, 2007a.

EEA: European Environmental Agency. Climate change: the cost of inaction and the cost of adaptation, EEA Technical report 13/2007, 2007b.

Frederick, K. D.: Adapting to climate impacts on the supply and demand for water, Clim. Change, 37, 141-156, 1997.

Giacomelli, P.: Economic evaluation of risk. The case of a mountain area, Aracne ed., Roma, 2005.
ISTAT: Italian census database, http://www.istat.it/censimenti/ popolazione/, last accessed 15 September 2007, 2001.

Lombardy Region: Direzione Generale Reti e Servizi di Pubblica Utilità, Programma di tutela e uso delle acque, Sometti, Mantova, 2006.

Lombardy Region: Direzione Generale Agricoltura. Atlante della bonifica e dell'irrigazione, Sometti, Mantova, 2003.

MED Joint Process WFD/EUWI: Water scarcity management in the context of WFD, Chapter I, p. 16, 2006.

NDMC: National Drought Mitigation Centre. Understanding and defining drought, http://drought.unl.edu/whatis/concept.htm, last accessed 16 July 2007, 2006.

Pearce, D.: Valuing risks in Calow P. eds handbook of environmental risk assessment and management, Blackwell Science, Oxford, UK, p. 345-378, 1998.

Petit, M.: Pressures on water resources: challenges for the agriculture, International conference "Water and irrigation development”, Cremona (Italy), 2001.

Polelli, M.: Nuovo trattato di estimo, edited by: Rimini, M., 2006.

Purchase, I. F. H.: Risk assessment. Principles and consequences, Pure Appl. Chem., 2(6), 1051-1056, 2000.

Ribaudo, F.: Prontuario di agricoltura per il geometra, il perito agrario e l'agrotecnico, Edagricole Bologna, 2004.

Sondrio Province: Volumi d'acqua turbinati dagli utenti idroelettrici, Settore lavori pubblici, pianificazione territoriale ed energia, Servizio acque ed energia, 2006.

Starmer, C. V.: The Economics of Risk, in: The handbook of environmental risk assessment and management, edited by: Calow, P., Blackwell Science, Oxford, UK, p. 319-344, 1998.

Sterlacchini, S., Frigerio, S., Giacomelli, P., and Brambilla, M.: Landslide risk analysis: a multi-disciplinary methodological approach, Nat. Hazards Earth Syst. Sci., 7, 657-675, 2007, http://www.nat-hazards-earth-syst-sci.net/7/657/2007/.

UNIONCAMERE: Regional Statistical Yearbook of Lombardy, http://www.ring.lombardia.it/asrnewe/index.html, last accessed 25 September 2007, 2005.

Wood, A. W., Lettenmaier, D. P., and Palmer, R. N.: Assessing climate change implications for water resources planning, Clim. Change, 37, 203-228, 1997. 